\title{
Клонирование и экспрессия гена целлюлазы Penicillium sp. 'occitanis' в Komagataella phaffii T07, выделение и анализ свойств
}

\author{
А.С. Розанов ${ }^{1,2}$ 凶, М.Е. Воскобоев ${ }^{1,2}$, Н.В. Богачева ${ }^{1,2}$, А.В. Коржук ${ }^{1,2}$, В.Н. Шляхтун ${ }^{1,2}$, И.А. Мещерякова ${ }^{1,2}$, \\ В.А. Романцев ${ }^{3}$, Д.В. Бочков ${ }^{1}$, А.В. Задорожный ${ }^{1,2}$, С.Е. Пельтек ${ }^{1,2}$
}

\begin{abstract}
Аннотация: Проведены клонирование и анализ свойств целлюлазы Penicillium sp. 'occitanis'. Ген был обнаружен в геномных данных базы NCBI. Получена плазмида PPZL-4xBGLU-Pocc, несущая четыре копии конструкции, экспрессирующей ген целлюлазы P. sp. 'occitanis'. Плазмида была клонирована в штамм дрожжей Komagataella phaffii Т07 под контроль промотора и терминатора гена AOX1. Было клонировано четыре копии экспрессирующей конструкции. В результате получен штамм K. phaffi Т07 BGLU-4хРосс. Максимальный уровень экспрессии этого штамма составил 4 000000 Ед/л культуральной жидкости при культивировании в 5-литровом биореакторе. Полученный белок, согласно данным гель-электрофореза, дает полосу 39.5 кДа, что соответствует расчетной массе, и обширную область примерно от 42 до 70 кДа. Формирование этой области говорит о возможном гликозилировании белка при экспрессии в K. phaffiі. Анализ свойств фермента показал, что температурный оптимум активности составляет $55-65^{\circ} \mathrm{C}$, рН оптимум - примерно 1.5-2. Фермент сохраняет $50 \%$ активности при рН от 1.5 до 6 и от 30 до $80^{\circ} \mathrm{C}$. Он стабилен при температуре ниже $75^{\circ} \mathrm{C}$ в течение 4 ч, но при $85^{\circ} \mathrm{C}$ за 4 ч теряет $50 \%$ активности. Фермент устойчив при рН от 4 до 7.5 .

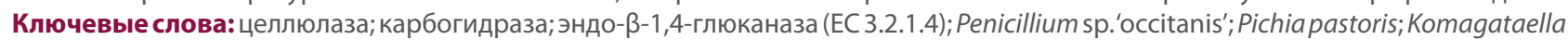
phaffi; биотехнология; культивирование.
\end{abstract}

Благодарности: Работа выполнена при финансовой поддержке Министерства науки и высшего образования Российской Федерации в рамках реализации комплексного проекта по созданию высокотехнологичного производства по теме: «Создание высокотехнологичного производства высококачественных растительных пищевых белков» (Соглашение о предоставлении из федерального бюджета субсидии на развитие кооперации государственного научного учреждения и организации реального сектора экономики в целях реализации комплексного проекта по созданию высокотехнологичного производства № 075-11-2020-036 от 15.12.2020) в рамках Постановления Правительства РФ от 9 апреля 2010 г. № 218 на базе ИЦиГ СО РАН. Авторы выражают благодарность ЦКП протеомного и метаболомного профилирования микроорганизмов, финансируемому из средств проекта № 0259-2021-0010.

Для цитирования: Розанов А.С., Воскобоев М.Е., Богачева Н.В., Коржук А.В., Шляхтун В.Н., Мещерякова И.А., Романцев В.А., Бочков Д.В., Задорожный А.В., Пельтек С.Е. Клонирование и экспрессия гена целлюлазы Penicillium sp. 'occitanis' в Komagataella phaffii Т07, выделение и анализ свойств. Письма в Вавиловский журнал генетики и селекции. 2021;7(4):194-200. DOI 10.18699/LettersVJ2021-7-24

\section{Original article}

\section{Cloning and expression of a cellulase gene from Penicillium sp. 'occitanis' in Komagataella phaffii T07}

\author{
A.S. Rozanov ${ }^{1,2} \bowtie$, M.E. Voskoboev ${ }^{1,2}$, N.V. Bogacheva ${ }^{1,2}$, A.V. Korzhuk ${ }^{1,2}$, V.N. Shlyahtun ${ }^{1,2}$, I.A. Mescheryakova ${ }^{1,2}$, \\ V.A. Romancev ${ }^{3}$, D.V. Bochkov ${ }^{1}$, A.V. Zadorozhnyy ${ }^{1,2}$, S.E. Peltek ${ }^{1,2}$
}

Abstract: In this study we cloned a cellulose from Penicillium sp. 'occitanis' and analyzed its properties. The gene was extracted from the NCBI database. We constructed a pPZL-4xBGLU-Pocc plasmid carrying four copies of a construction capable of expressing the $P$. sp. 'occitanis' cellulase. The plasmid was inserted into the Komagataella phaffii T07 yeast strain under the control of AOX1 promoter and terminator. A total of four copies of the expressed construction was cloned. As the result, we obtained the K. phaffii T07 BGLU-4xPocc

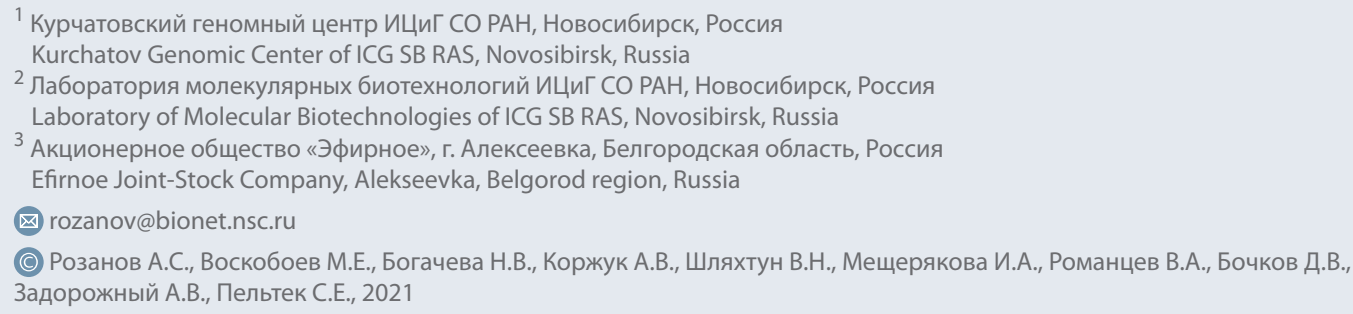


strain. The maximum expression level of the strain was $\sim 4000000 \mathrm{U}$ per $1 \mathrm{I}$ of culture media in a $5 \mathrm{I}$ bioreactor. The obtained protein was seen as a $\sim 39.5 \mathrm{kDa}$ band on the gel, which accords with its calculated mass. It also formed a smear from about 42 to $70 \mathrm{kDa}$, which probably indicates its glycosylation during the expression in $K$. phaffii. The temperature optimum of the enzyme was at $55-655^{\circ} \mathrm{C}$, and $\mathrm{pH}$ at $\sim 1.5-2$. The enzyme retains at least $50 \%$ activity at $\mathrm{pH}$ ranging from 1.5 to 6 , and at 30 to $80^{\circ} \mathrm{C}$. Below $75^{\circ} \mathrm{C}$, the protein remains active for $4 \mathrm{~h}$. At $85^{\circ} \mathrm{C}$, it loses $50 \%$ of its activity after $4 \mathrm{~h}$. The enzyme is stable in pH ranging from 4 to 7.5 .

Key words: cellulase; carbohydrase; endo- $\beta-1,4-$ glucanase (EC 3.2.1.4); Penicillium sp. 'occitanis'; Pichia pastoris; Komagataella phaffii; biotechnology; cultivation.

Acknowledgements: The study was funded by the Ministry of Science and Higher Education of the Russian Federation as a part of the comprehensive project on high-tech industry "Creation of high-tech production of high-quality plant food proteins" (The agreement on the provision of subsidies from the federal budget for the development of cooperation of a state scientific institution and organization the real sector of the economy in order to implement a comprehensive project for the creation of high-tech industry No. 075-11-2020-036 from 15.12.2020) in the framework of the Decree of the Government of the Russian Federation of April 9, 2010 No. 218 on the basis of the ICG SB RAS. We thank ICG SB RAS Core Facility of Proteomic and metabolomic profiling of microorganisms (supported by project No. 0259-2021-0010).

For citation: Rozanov A.S., Voskoboev M.E., Bogacheva N.V., Korzhuk A.V., Shlyahtun V.N., Mescheryakova I.A., Romancev V.A., Bochkov D.V., Zadorozhnyy A.V., Peltek S.E. Cloning and expression of a cellulase gene from Penicillium sp. 'occitanis'in Komagataella phaffii T07. Pismav Vavilovskii Zhurnal Genetiki i Selektsii = Letters to Vavilov Journal of Genetics and Breeding. 2021;7(4):194-200. DOI 10.18699/LettersVJ2021-7-24 (in Russian)

\section{Введение}

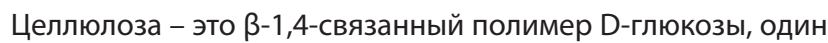
из основных компонентов клеточной стенки растений, самый массовый компонент биосферы и наиболее распространенный возобновляемый источник углерода на Земле. Ежегодная продукция целлюлозы составляет примерно $10^{12}$ т в год (Tomme et al., 1995; Watanabe et al., 2001). В связи с такими значительными объемами ежегодной продукции целлюлоза является важным компонентом круговорота углерода в биосфере. Целлюлоза клеточной стенки находится в составе пространственного комплекса с гемицеллюлозой и лигнином. Три полимера, входящие в состав клеточной стенки, обладают разными свойствами и совместно обеспечивают физическую и химическую стойкость лигноцеллюлозы, которая обеспечивает структурную функцию растительной биомассы.

Биологическое разложение лигноцеллюлозы в природе происходит под воздействием большой группы ферментов: целлюлаз, гемицеллюлаз и лакказ. В большинстве случаев полный комплекс лигноцеллюлозоразрушающих ферментов синтезируется группой организмов. Непосредственно разрушение целлюлозы осуществляют три типа фермен-

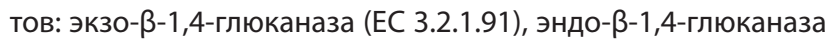

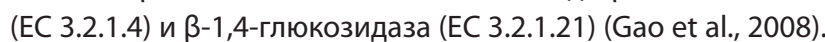
Основные деструкторы целлюлозы - это грибы, они же служат источником большинства генов $\beta$-1,4-гликозид гидролаз, применяемых в технологических процессах.

Первой коммерчески доступной целлюлазой стал ферментный препарат, получаемый из белков, секретируемых грибком Trichoderma reesi (Wang et al., 2013). Секрет T. reesi состоит из комплекса генов $\beta$-1,4-гликозид гидролаз и используется в основном для разложения лигноцеллюлозной биомассы. Параллельно с развитием методов молекулярной биологии, белковой и геномной инженерии исследователи осуществили оптимизацию этого комплекса, а позднее перенесли синтез препарата в другие, уже рекомбинантные продуценты (Bhati, Sharma, 2021). По мере роста спектра применений целлюлаз и повышения требований к их стабильности происходил поиск новых генов, более адап- тированных к требованиям технологических процессов целлюлаз. В том числе возникла потребность в получении препаратов, состоящих из отдельных целлюлаз (Kumar et al., 2019; Siqueira et al., 2020; Niyonzima, 2021). Поиск новых генов целлюлаз остается актуальным и в настоящее время, что связано как с общим развитием биотехнологического направления, так и с развитием локальных производств ферментов.

В исследовании мы использовали дрожжи Komagataella phaffii (Pichia pastoris), которые применяются в качестве продуцента рекомбинантного белка с 70-х годов прошлого столетия (Ahmad et al., 2014). Эти дрожжи обладают развитой системой секреции белков и способностью к росту до очень высоких плотностей культуры, что позволяет получать ферменты в высокой концентрации (Bill, 2014). Дрожжевая система экспрессии гетерологичных белков становится все более популярной ввиду удобства ее использования в производственных условиях.

За последние несколько лет опубликованы работы, посвященные экспрессии эндоглюканаз в K. phaffii. Так, с 2018 г. успешно экспрессированы целлюлаза из: Aspergillus fumigatus (Vianna Bernardi et al., 2019), A. awamori (Liu et al., 2020), Thermoascus aurantiacus (Jain et al., 2018), Sclerotinia sclerotiorum (Chahed et al., 2018), Reticulitermes speratus (Zhang et al., 2018), Thermoanaerobacter brockii (Javanmard et al., 2021) и др. В работе (Javanmard et al., 2021) выполнено клонирование целлюлазы из гриба T. brockii. Помимо анализа полученного рекомбинантного белка показано положительное влияние введения нескольких копий экспрессирующих конструкций на уровень наработки белка (Javanmard et al., 2021).

В настоящее время одним из наиболее значимых источников информации о последовательностях генов микроорганизмов становятся открытые базы данных. В связи с увеличением объемов секвенирования постоянно растет объем информации о геномах микроорганизмов, что приводит к экспоненциальному росту данных о геномных последовательностях. Мы провели поиск генов целлюлаз и обнаружили ряд генов, которые ранее не были изучены. Эти последовательности использовали для получения реком- 
бинантного белка с предсказанными свойствами, не имея генетического материала микроорганизма, в котором ген был обнаружен.

\section{Материалы и методы}

Конструирование экспрессионных кассет и интеграционного вектора. Поиск гена целлюлазы. Для получения последовательностей генов белков, адаптированных для экспрессии в K. phaffii, были удалены сигнальные пептиды, обнаруженные в аминокислотных последовательностях при помощи программы SignalP-5.0 (http://www.cbs.dtu.dk/ services/SignalP/). Последовательность гена была оптимизирована для экспрессии в K. phaffii фирмой ATG:biosynthetics (Германия). Для сборки экспрессирующей конструкции применены метод Gibson Assembly и набор NEBuilder HiFi 2X Master Mix (NewEnglandBiolabs, США), согласно инструкции производителя. Фрагменты для сборки амплифицировали при помощи ПЦР с высокоточной полимеразой Q5 ${ }^{\circledR}$ HighFidelity 2X Master Mix (NewEnglandBiolabs). Для получения фрагментов с перекрывающимися концами были взяты праймеры с довесками (табл. 1).

Для сборки плазмиды, несущей четыре копии конструкции, экспрессирующей ген целлюлазы, амплифицировали экспрессирующую конструкцию праймерами BglAoxProm_F и BamHIAoxTerm_R с использованием Q5 полимеразы. Полученный фрагмент обрабатывали рестриктазами Mall, Bglll и BamHI, очищали на магнитных частицах и клонировали в плазмиду pPZL-BGLU-Росс, обработанную рестриктазой Bglll. Процедуру повторяли три раза, пошагово наращивая копийность.

Конструирование штамма продуцента. Электрокомпетентные клетки трансформировали плазмидой PPZL-4xBGLU-Pocc, несущей четыре копии конструкции, экспрессирующей ген целлюлазы Penicillium sp. 'occitanis'. Добавляли к компетентным клеткам 1 мл одномолярного раствора сорбитола и инкубировали в течение 2 ч при $30{ }^{\circ} \mathrm{C}$. После чего высевали часть культуры на агаризованную среду YPD с зеоцином в качестве селективного антибиотика. Чашки Петри культивировали в течение 3 суток при $30^{\circ} \mathrm{C}$.

Отбор клонов. Для отбора клонов с наибольшей целлюлазной активностью выросшие колонии К. phaffii Т07, трансформированные плазмидой pPZL-4xBGLU-Pocc, засевали в 24-луночный планшет с глубокими лунками. Каждую колонию помещали в отдельную ячейку, содержащую 2 мл YPGM с 0.3 \% глюкозы и 1 \% метанола. В качестве отрицательного контроля был штамм K. phaffii Т07 без встроенного гена целлюлазы. Планшет инкубировали в термошейкере при $30^{\circ} \mathrm{C}, 380$ об/мин в течение 3 суток. Каждые сутки добавляли 20 мкл метанола в каждую ячейку планшета.

На четвертые сутки культивирования отбирали по 500 мкл культуры из каждой ячейки планшета, переносили в 1.5 мл пробирки, осаждали клетки центрифугированием при $4000 \mathrm{~g}$ в течение 15 мин. Полученный супернатант использовали для определения целлюлазной активности.

Культивирование штамма продуцента в биореакторе. Культивирование рекомбинантного штамма К. phaffii Т07 в ферментереосуществлялив соответствиисметодом, описан- ным в руководстве по системе экспрессии Pichia Expression Kit (Invitrogen). Отдельные колонии штамма K. phaffii T07 c чашки YPD с зеоцином (200 мкг/мл) инокулировали в 5 мл среды YPD с зеоцином (200 мкг/мл) и культивировали в течение ночи при $30^{\circ} \mathrm{C}$ в качестве посевной культуры. Посевную культуру (4 мл) дополнительно инокулировали в 400 мл (4 колбы на 500 мл по 100 мл среды) смеси сред YPD и ҮNB (1:4) с 2 \% глюкозы и культивировали в течение 48 ч при $30^{\circ} \mathrm{C}$ и 250 об/мин.

Для инокуляции 4 л солевой среды, содержащей 32.5 г/л глицерина, 9.375г/л $\left(\mathrm{NH}_{4}\right)_{2} \mathrm{SO}_{4}, 1.875 г / л \mathrm{CaSO}_{4} \cdot 2 \mathrm{H}_{2} \mathrm{O}, 0.9375 г / л$ $\mathrm{NaCl}, 3.75$ г/л $\mathrm{MgSO}_{4} \cdot 7 \mathrm{H}_{2} \mathrm{O}, 3.75$ г/л $\mathrm{KH}_{2} \mathrm{PO}_{4}$ в 7.5-литровом ферментере Pro-Lab (Биотехно, Москва) использовали 400 мл культуры. Культивирование проводили при $30^{\circ} \mathrm{C}$ с постоянным потоком воздуха 3 л/мин. Начальная скорость вращения мешалки составила 400 об/мин. Содержание растворенного кислорода поддерживали на уровне более $20 \%$ при помощи постепенного увеличения скорости вращения мешалки до 1200 об/мин, рН среды поддерживали на уровне 5.9, используя $10 \mathrm{M}$ раствор $\mathrm{NaOH}$. Перед инокуляцией в среду добавляли 2.5 мл/л микроэлементов (табл. 2), 2.5 мл/л витаминов (табл. 3) и 0.25 г/л ампициллина.

После выедания глицерина культурой биомасса достигает 90 г/л. Момент полного выедания глицерина отслеживали по резкому увеличению содержания растворенного кислорода. При проявлении скачка кислорода переходили на стадию индукции и добавляли в биореактор через 0.2 микронный фильтр 2 мл/л микроэлементов и 2 мл/л $50 \%$ раствора $\left(\mathrm{NH}_{4}\right)_{2} \mathrm{SO}_{4}$. Далее переводили культуру на питание метанолом, который является индуктором промотора $A O X 1$, для чего применяли 60 \% метанол. Стадию индукции начинали с добавления 40 мл индуктора и снижения температуры до $27^{\circ} \mathrm{C}$. Как только культура адаптировалась к метанолу и уровень кислорода опускался ниже $20 \%$, запускали периодическую подпитку метанолом. Подпитку проводили по 4 мл индуктора каждые 20 мин первые три часа после индукции и по 6.7 мл индуктора до конца культивирования, при резком росте растворенного кислорода выше $25 \%$ добавляли 40 мл индуктора. Периодически собирали образцы для мониторинга ферментативной активности культуральной жидкости и роста биомассы. По достижению культурой массы 150 г/л опускали температуру культуры до $23^{\circ} \mathrm{C}$. Культивирование проводили в течение 72 ч после начала индукции.

Методика определения целлюлазной активности в супернатанте. За основу для определения ферментативной активности взяли методику, описанную в учебном издании Х. Биссвангера «Практическая энзимология» (2010). Метод заключается в расщеплении карбоксиметилцеллюлозы (КМЦ) ферментом до восстанавливающих сахаров и восстановлении ими 3.5-динитросалициловой кислоты (ДНСК) до 3-амино-5-нитросалициловой кислоты, обладающей красно-оранжевой окраской, интенсивность которой определяют колориметрически при длине волны 546 нм.

Для данной методики отбирали супернатант, полученный путем центрифугирования клеточной культуры дрожжей. Супернатант смешивали с 1 \% КМЦ и инкубировали в течение 20 мин, после чего к реакционной смеси добавля- 
Таблица 1. Праймеры, использованные в работе

\begin{tabular}{ll}
\hline Название & Нуклеотидная последовательность \\
\hline Aox-term_to_gene_F & 5'-GCCTTAGACATGACTGTTCCTCAGT-3' \\
\hline alpha_to_gene_R & 5'-AGCTTCAGCCTCTCTTTTCTCG-3' $^{\prime}$ \\
\hline BGLU_Pocc_pPZL_gibsonF & 5'-CGAGAAAAGAGAGGCTGAAGCTGCCGGTGCTGTTAAAACTGTTAC-3' \\
\hline BGLU_Pocc_pPZL_gibsonR & 5'-AGGAACAGTCATGTCTAAGGCTTAAGGGAAGTAGGACTCAAGAATGGAC-3' \\
\hline BglAoxProm_F & 5'-atgcatgcAGATCTAACATCCAAAGACGAAAGG-3' \\
\hline BamHIAoxTerm_R & 5'-atgcatgcGGGATCCGCACAAACGAAGG-3' \\
\hline
\end{tabular}

Таблица 2. Раствор микроэлементов

\begin{tabular}{ll}
\hline Компонент & $\begin{array}{l}\text { Кол-во (г) } \\
\text { на } 1000 \text { мл }\end{array}$ \\
\hline Сульфат меди 5-водный $\left(\mathrm{CuSO}_{4} \cdot 5 \mathrm{H}_{2} \mathrm{O}\right)$ & 3 \\
\hline Иодид натрия (Nal) & 0.4 \\
\hline Сульфат марганца $\left(\mathrm{MnSO}_{4}\right)$ & 2 \\
\hline Молибдат натрия 2-водный $\left(\mathrm{Na}_{2} \mathrm{MoO}_{4} \cdot 2 \mathrm{H}_{2} \mathrm{O}\right)$ & 1 \\
\hline Борная кислота $\left(\mathrm{H}_{3} \mathrm{BO}_{3}\right)$ & 0.1 \\
\hline Хлорид кобальта 6-водный $\left(\mathrm{CoCl}_{2} \cdot 6 \mathrm{H}_{2} \mathrm{O}\right)$ & 0.5 \\
\hline Сульфат железа 7-водный $\left(\mathrm{FeSO}_{4} \cdot 7 \mathrm{H}_{2} \mathrm{O}\right)$ & 33 \\
\hline Серная кислота $\left(\mathrm{H}_{2} \mathrm{SO}_{4}\right)$ & 5 мл \\
\hline Сульфат цинка $\left(\mathrm{ZnSO}_{4} \cdot 7 \mathrm{H}_{2} \mathrm{O}\right)$ & 5 \\
\hline
\end{tabular}

Таблица 3. Раствор витаминов

\begin{tabular}{ll}
\hline Компонент & $\begin{array}{l}\text { Кол-во (г) } \\
\text { на } 1000 \text { мл }\end{array}$ \\
\hline Биотин & 0.0508 \\
\hline Пантотенат кальция & 0.2 \\
\hline Фолиевая кислота & 0.01 \\
\hline Инозитол & 1 \\
\hline Ниацин & 0.2 \\
\hline п-Аминобензойная кислота & 0.1 \\
\hline Пиридоксина гидрохлорид & 0.2 \\
\hline Рибофлавин & 0.1 \\
\hline Тиамина гидрохлорид & 0.2 \\
\hline
\end{tabular}

ли два объема 1 \% ДНСК. Эту смесь прогревали при $95^{\circ} \mathrm{C}$ в течение 10 мин, затем охлаждали до комнатной температуры. Оценку активности созданных ферментных препаратов проводили на спектрофотометре Epoch BioTek с помощью программного обеспечения Gen5. В лунки спектрофотометрического планшета наносили по 200 мкл анализируемой смеси.

Определение рН оптимума и стабильности. Для каждой реакции объемом 100 мкл отбирали по 50 мкл культуральной жидкости и добавляли 50 мкл 1 \% КМЦ. Для каждого $\mathrm{pH}$ был приготовлен отдельный раствор $1 \%$ КМЦ, диапазон pH - от 6.5 до 10 с шагом 0.5. Реакции проводили в 96-луночном планшете на амплификаторе T100 (Bio-Rad, США) в течение 20 мин при температуре $40^{\circ} \mathrm{C}$. После окончания инкубации 75 мкл реакционной смеси смешивали с 150 мкл ДНСК и инкубировали в течение 10 мин при $95^{\circ} \mathrm{C}$.

Определение температурного оптимума. Для каждой реакции объемом 100 мкл отбирали по 50 мкл культуральной жидкости и добавляли 50 мкл $1 \%$ КМЦ с рН буферного раствора 6.5. Реакции проводили в 96-луночном планшете на амплификаторе T100 (Bio-Rad) в градиенте температур от 45 до $70^{\circ} \mathrm{C}$ в течение 20 мин. После окончания инкубации 75 мкл реакционной смеси смешивали с 150 мкл ДНСК и инкубировали в течение 10 мин при $95^{\circ} \mathrm{C}$.

Очистка и SDS-PAGE. Все операции проводили при температуре, не превышающей $(3 \pm 2)^{\circ} \mathrm{C}$. Культуральную жидкость центрифугировали в течение 25 мин при 4000 об/мин. Супернатант очищали от низкомолекулярных примесей и концентрировали в 20 раз методом ультрафильтрации с использованием центрифужных концентраторов типа Vivaspin 20 и картриджей, имеющих размер пор мембраны 10 кДа. Для постановки SDS-PAGE концентрат промывали дистиллированной водой.

Полученный ферментативный препарат упаривали в 20 раз на центрифужном испарителе Concentrator plus (Eppendorf), смешивали c Laemmli буфером (62.5 мМ Tрис-HCl $\mathrm{pH}$ 6.8, 25 \% глицерина, 2 \% ДСН, 0.01 \% бромфенолового синего, $5 \%$ меркаптоэтанола) в соотношении 1:2 и нагревали при $95{ }^{\circ} \mathrm{C}$ в течение 5 мин, затем по 30 мкл наносили в карманы 4 \% концентрирующего полиакриламидного геля (4 \% смеси акриламида с бисакриламидом 37.5:1,125 мМ Трис- $\mathrm{HCl}$ pH 6.8, 0.1 \% ДСН, 0.5 \% персульфата аммония и $0.1 \% \mathrm{~N}, \mathrm{~N}, \mathrm{~N}$, N'-тетраметилэтилендиамина). Разделение образцов проводили в 12 \% полиакриламидном геле (12 \% смеси акриламида с бисакриламидом 37.5:1.375 мМ Трис-HCl pH 8.8, 0.1\% ДСН, $0.5 \%$ персульфата аммония и $0.05 \%$ N, N, N', N'-тетраметилэтилендиамина) при 200 В на гель В трис-глициновом буфере (25 мМ трис, 192 мМ глицин, 0.1 \% ДСН). Гель окрашивали по Кумасси и визуализировали при помощи гельдокументирующей системы VersaDoc (Bio-Rad).

\section{Результаты}

\section{Поиск гена}

Последовательности целлюлаз можно найти при использовании гомологии к уже известным в настоящее время ферментам, с применением алгоритмов множественного выравнивания и информации из открытых баз данных. 
Наиболее стабильной среди грибных целлюлаз является описанная ранее $\beta$-глюканаза из термотолерантного гриба Talaromyces emersonii (Wang et al., 2014). Последовательность целлюлазы приведена далее:

>AHV83755.1 glucanase Egl5A (Rasamsonia emersonii) MKFSRVVCGLTEAGGALAAPVKEKGIKKRASPFQWFGSNESGAEFGNNNIPGVEGTDYTFPNTSAIQILIDQGMNIFRVPFLMERMVPNQMTGPVDSAYFQGYSQVINYITSHGASAVIDPHNFGRYYNNIISSPSDFQTFWHTIASNFADNDNVIFDTNNEYHDMDESLVVQLNQAAIDGIRAAGATSQYIFVEGNSWTGAWTWTQVNDAMANLTDPQNKIVYEMHQYLDSDGSGTSDQCVNSTIGQDRVESATAWLKQNGKKAILGEYAGGANSVCETAVTGMLDYLANNTDVWTGAIWWAAGPWWGDYIF-

\section{SMEPPSGIAYEQVLPLLKPYLE}

С помощью этой последовательности был выполнен поиск похожих генов. В результате была найдена группа генов, имеющих уровень гомологии более 30 \% к эталонной последовательности, среди которых для работы была отобрана следующая последовательность:

>PCH03425.1 Glycoside hydrolase, superfamily (Penicillium sp. 'occitanis')

MAGAVKTVTTLKTDRTSDSSENTSQENLITMKTSIISIVLSTAGLTLGAPSKDTKKRASSFEWFGSNESGAEFGSGNIPGVEGTDYTFPNTTAIQILIDAGMNIFRVPFLMERMIPTEMTGSLNTAYFEGYSEVINYITGQGAHAVVDPHNFGRYYGTPISSTSDFQTFWSTLASQFKSNDKVIFDTNNEYHDMDESVVVALNQAAIDGIRDAGATTQYIFVEGNSYTGAWTWTTYNTAMVNLTDPSDLIVYEMHQYLDSDGSGTSDQCVSSTIGQERVVDATTWLQTNGKRGILGEFAGGANSVCEEAVKGMLNYLEQNSDVWLGASWWSAGPWWGDYIFSMEPPSGTAYVNYLSILESYFP

Последовательность была найдена в геноме, аннотированном при подготовке работы, направленной на изучение патогенности грибов к растениям (Bravo-Ruiz et al., 2017). По этой последовательности была получена химически синтезированная последовательность гена с кодонным составом, оптимизированным для экспрессии в K. phaffiі (данные не представлены).

\section{Конструирование вектора}

С применением полученной ранее в лаборатории плазмиды PPZL была сконструирована плазмида на основе вектора PPZL, несущая конструкцию, экспрессирующую целлюлазу P. sp. 'occitanis' под контролем промотора и терминатора гена AOX1. Далее плазмида PPZL-BGLU-Pocc была использована для конструирования плазмиды pPZL-4xBGLU-Pocc, несущей четыре копии конструкции, экспрессирующей ген целлюлазы P. sp. 'occitanis', как это принято в биотехнологической промышленности.

\section{Скрининг наиболее активных клонов}

Плазмида pPZL-4xBGLU-Poсc была клонирована в штамм K. phaffii Т07 при помощи электропорации. Выросшие на селективной среде на 3-й день колонии были проверены на наличие целлюлазной активности. Все проанализированные клоны (16) продемонстрировали целлюлазную активность. Клон, проявивший наибольшую активность, был использован для дальнейшей работы. Штамму было присвоено название K. phaffii T07 BGLU-4xPOcc.
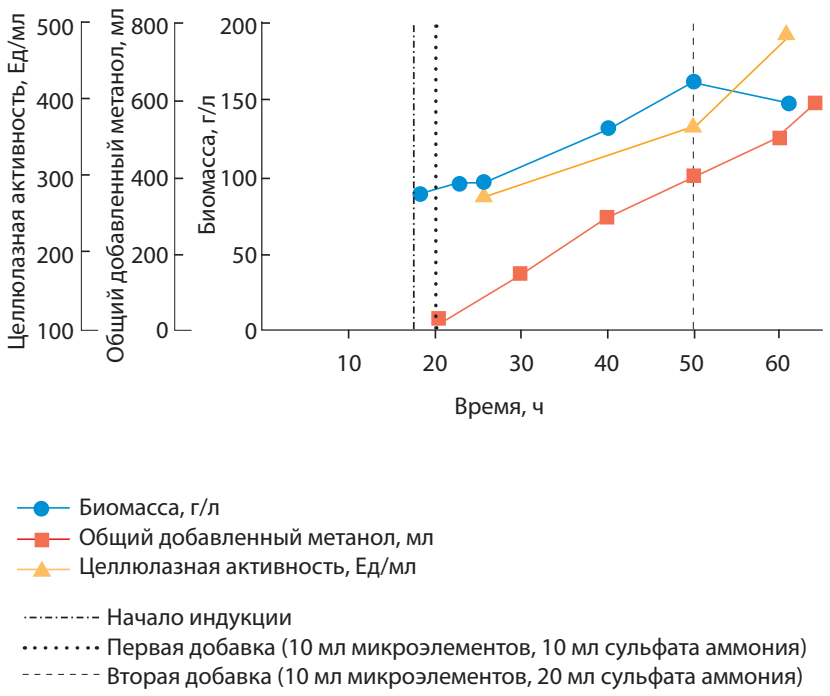

Рис. 1. Параметры роста культуры К. phaffii T07 BGLU-4xPocc при культивировании в биореакторе

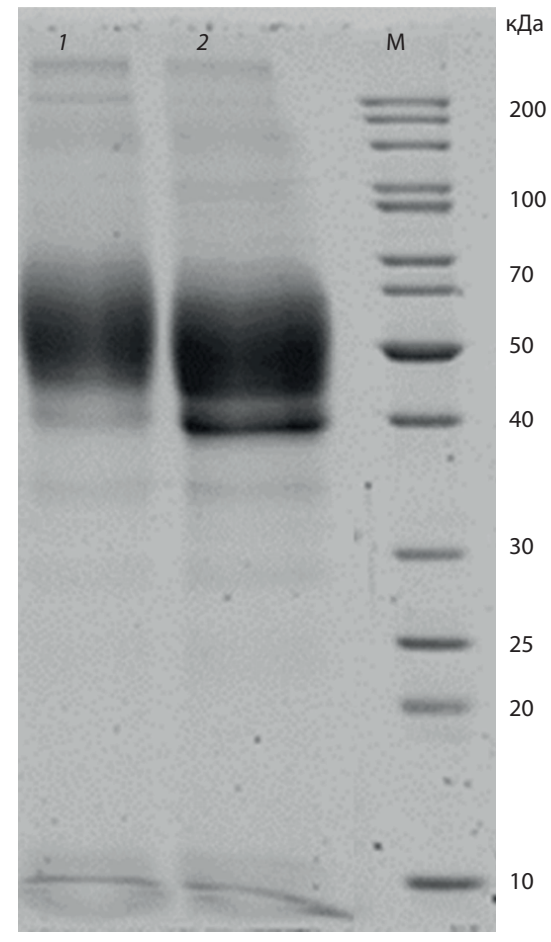

Рис. 2. Гель с разделенными образцами концентрированных культуральных жидкостей штаммов, экспрессирующих эндоглюканазу Penicillium sp. 'occitanis' $(1,2)$.

M - маркер молекулярного веса (кДа, приведен справа)

\section{Наработка ферментативного препарата}

Выбранный штамм культивировали в биореакторе, согласно методике, представленной в разделе «Материалы и методы». Культивирование длилось 42 ч после индукции, максимум целлюлазной активности был через 40 ч после индукции. Наибольшее содержание биомассы - через 32 ч после начала индукции (рис. 1). Максимальная активность, 

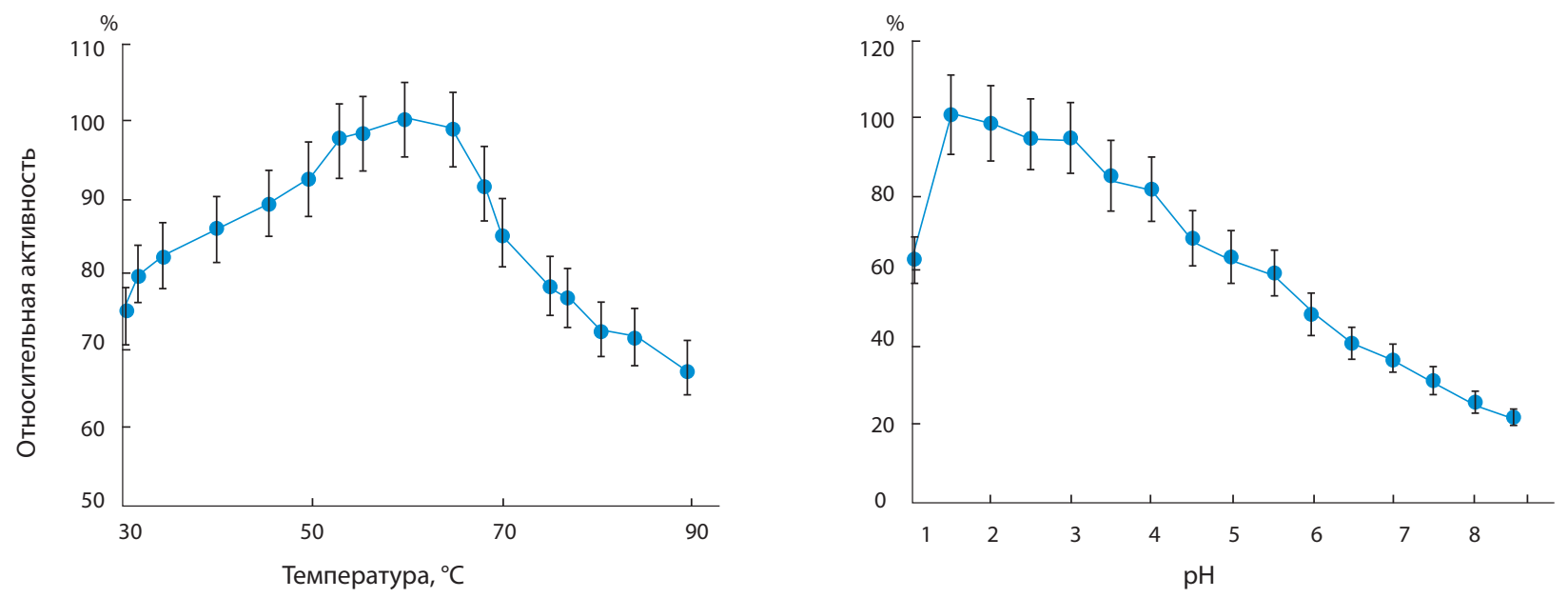

Рис. 3. Зависимость активности фермента целлюлазы P. sp. 'осcitanis' от температуры (слева) и рH (справа)
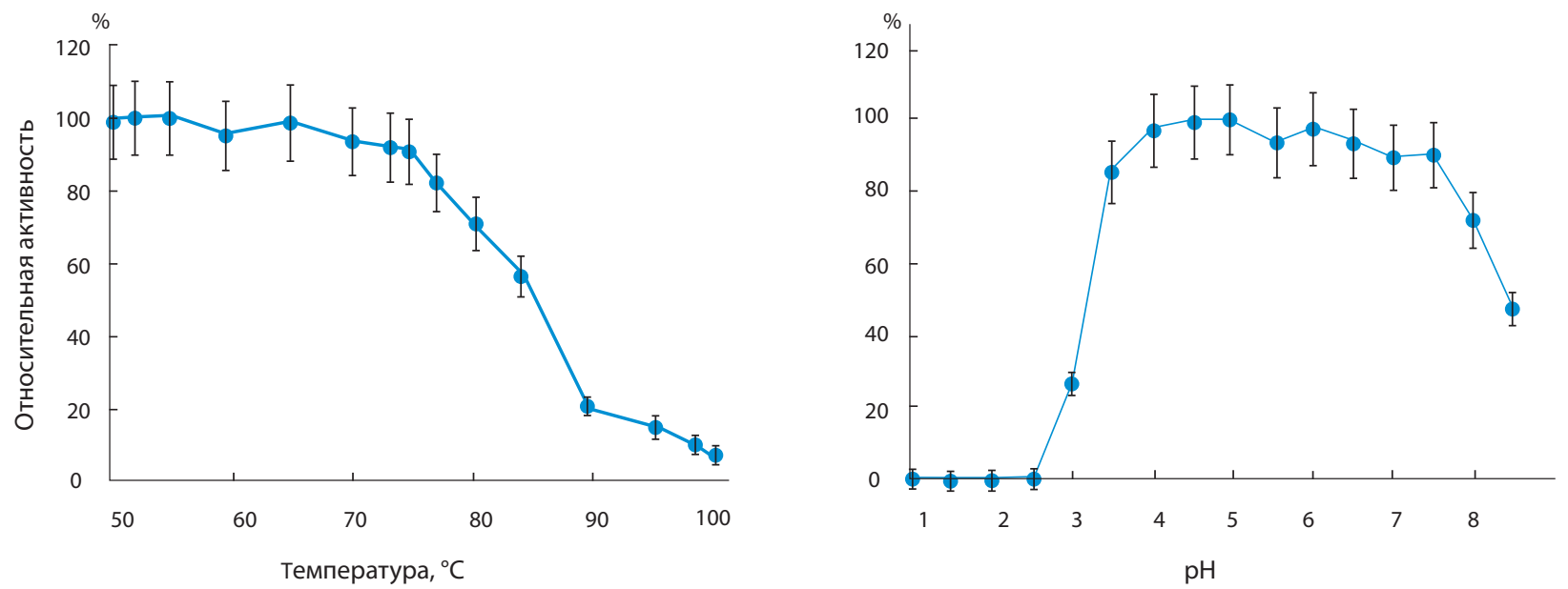

Рис. 4. Зависимость стабильности фермента целлюлазы P. sp. 'осcitanis' от температуры (слева) и рH (справа)

которая была получена при культивировании в биореакторе, составила 4 000000 Ед/л культуральной жидкости.

\section{Анализ препарата при помощи SDS-PAAG}

Созданный в ходе ферментации ферментативный препарат исследовали при помощи SDS-PAAG, согласно методике, приведенной в разделе «Материалы и методы» (рис. 2).

На полученном гель-электрофорезе можно наблюдать достаточно четкую полосу чуть ниже 40 кДа, которая соответствует расчетной молекулярной массе рекомбинантного белка целлюлазы P. sp. 'occitanis', составляющей 39562.67 Да. Выше этой полосы наблюдается бэнд в виде широкой области, примерно от 42 до 70 кДа. Предположительно, это рекомбинантный белок с разным уровнем гликозилирования.

\section{Определение свойств фермента}

Поставлен эксперимент по выявлению активности при разных температурах и рН (рис. 3). Эксперименты проводили в трех повторностях.
Согласно полученным данным, оптимум активности фермента целлюлазы P. sp. 'occitanis' находится в диапазоне температуры $55-65^{\circ} \mathrm{C}$ и рН 1.5-3. Активность имеет практически линейную обратную зависимость от $\mathrm{pH}$ и в условиях эксперимента постепенно растет от 8.5 до 1.5. Далее при $\mathrm{pH}=1$ начинает резко снижаться. Зависимость активности от температуры имеет классический куполообразный вид.

Поставлен эксперимент по определению стабильности фермента при разных значениях температуры и рН. Для определения $\mathrm{pH}$ стабильности фермент выдерживали при температуре $50^{\circ} \mathrm{C}$ и рН от 1 до 8.5. Затем осуществляли ферментативную реакцию. Для определения оптимума температуры фермент выдерживали при рН 8.0 и температурах от 50 до $100{ }^{\circ} \mathrm{C}$. После чего проводили ферментативную реакцию (рис. 4). Эксперименты выполняли в трех повторностях.

Фермент сохраняет стабильность при температуре ниже $75^{\circ} \mathrm{C}$ в течение 4 ч, а при $85^{\circ} \mathrm{C}$ за 4 ч теряет $50 \%$ активности. Он стабилен при рН от 4 до 7.5 . 


\section{Заключение}

Выполнены клонирование и анализ свойств ранее не исследованного белка целлюлазы из Р. sp. 'occitanis'. Ген был обнаружен в базе NCBI. Синтезирован ген с кодонной последовательностью, адаптированной для экспрессии в дрожжах K. phaffii. Получена плазмида pPZL-4xBGLU-Pocc, несущая четыре копии конструкции, экспрессирующей ген целлюлазы P. sp. 'occitanis'. Плазмида клонирована в штамм дрожжей K. phaffii Т07 под контроль промотора и терминатора гена AOX1. Было клонировано четыре копии экспрессирующей ген конструкции в геном. В результате получен штамм K. phaffii T07 BGLU-4xPocc. Максимальный уровень экспрессии полученного штамма составил 4 000000 Ед/л культуральной жидкости при культивировании в 5-литровом биореакторе. Полученный белок, согласно результатам гель-электрофореза, дает полосу 39.5 кДа, что соответствует расчетному весу, и обширную область примерно от 42 до 70 кДа, формирование которой говорит о гликозилировании белка при экспрессии в K. phaffii.

Анализ свойств фермента показал, что оптимум активности наблюдался при 55-65 ${ }^{\circ} \mathrm{C}$, и рН 1.5-2. Фермент сохраняет $50 \%$ активности при рН от 1.5 до 6 и от 30 до $80^{\circ} \mathrm{C}$. Он также сохраняет стабильность при температуре ниже $75^{\circ} \mathrm{C}$ в течение 4 ч, а при $85^{\circ} \mathrm{C}$ за 4 ч теряет $50 \%$ активности. Фермент стабилен при $\mathrm{pH}$ от 4 до 7.5. Несмотря на то что оптимум ферментативной активности рН находится около 2, целесообразно использовать фермент при более высоких значениях $\mathrm{pH} \sim$, так как при этом фермент стабилен.

\section{Список литературы / References}

Биссвангер Х. Практическая энзимология. Пер. с англ. М.: Бином. Лаборатория знаний, 2010;154-156.

[Bisswanger H. Practical Enzymology. Moscow: Binom Publ., 2010;154-156. (in Russian)]

Ahmad M., Hirz M., Pichler H., Schwab H. Protein expression in Pichia pastoris: recent achievements and perspectives for heterologous protein production. Appl. Microbiol. Biotechnol. 2014;98(12):53015317. DOI 10.1007/s00253-014-5732-5.

Bhati N., Sharma A.K. Cost-effective cellulase production, improvement strategies, and future challenges. J. Food Process Eng. 2021;44(2):e13623. DOI 10.1111/jfpe.13623.

Bill R.M. Playing catch-up with Escherichia coli: using yeast to increase success rates in recombinant protein production experiments. Front. Microbiol. 2014;5:85. DOI 10.3389/fmicb.2014.00085.

Bravo-Ruiz G., Sassi A.H., Marcet-Houben M., Di Pietro A., Gargouri A., Gabaldon T., Roncero M.I.G. Regulatory mechanisms of a highly pectinolytic mutant of Penicillium occitanis and functional analysis of a candidate gene in the plant pathogen Fusarium oxysporum. Front. Microbiol. 2017;8:1627. DOI 10.3389/fmicb.2017.01627.

Chahed H., Boumaiza M., Ezzine A., Marzouki M.N. Heterologous expression and biochemical characterization of a novel thermostable Sclerotinia sclerotiorum GH45 endoglucanase in Pichia pastoris. Int. J. Biol. Macromol. 2018;106:629-635. DOI 10.1016/j.ijbiomac.2017.08.062.

Gao J., Weng H., Zhu D., Yuan M., Guan F., Xi Y. Production and characterization of cellulolytic enzymes from the thermoacidophilic fungal Aspergillus terreus M11 under solid-state cultivation of corn stover. Bioresour. Technol. 2008;99(16):7623-7629. DOI 10.1016/ j.biortech.2008.02.005.

Jain K.K., Kumar S., Bhardwaj K.N., Kuhad R.C. Functional expression of a thermostable endoglucanase from Thermoascus aurantiacus RCKK in Pichia pastoris X-33 and its characterization. Mol. Biotechnol. 2018;60(10):736-748. DOI 10.1007/s12033-018-0106-3.

Javanmard A.S., Matin M.M., Bahrami A.R. Polycistronic cellulase gene expression in Pichia pastoris. Biomass Convers. Biorefin. 2021;1-13. DOI 10.1007/s13399-021-01765-7.

Kumar V.A., Kurup R.S.C., Snishamol C., Prabhu G.N. Role of cellulases in food, feed, and beverage industries. In: Parameswaran B., Varjani S., Raveendran S. (Eds.). Green Bio-processes. Energy, Environment, and Sustainability. Singapore: Springer, 2019;323-343. DOI 10.1007/978981-13-3263-0_17.

Liu X., Jiang Z., Ma S., Yan Q., Chen Z., Liu H. High-level production and characterization of a novel $\beta-1,3-1,4-$ glucanase from Aspergillus awamori and its potential application in the brewing industry. Process Biochem. 2020;92:252-260. DOI 10.1016/j.procbio.2020.01.017.

Niyonzima F.N. Detergent-compatible fungal cellulases. Folia Microbiol. 2021;66(1):25-40. DOI 10.1007/s12223-020-00838-w.

Siqueira J.G.W., Rodrigues C., de Souza Vandenberghe L.P., Woiciechowski A.L., Soccol C.R. Current advances in on-site cellulase production and application on lignocellulosic biomass conversion to biofuels: a review. Biomass Bioenergy. 2020;132:105419. DOI 10.1016/j.biombioe.2019.105419.

Tomme P., Warren R.A.J., Gilkes N.R. Cellulose hydrolysis by bacteria and fungi. Adv. Microb. Physiol. 1995;37:1-81. DOI 10.1016/S00652911(08)60143-5.

Vianna Bernardi A., Kimie Yonamine D., Akira Uyemura S., Magnani Dinamarco T. A thermostable Aspergillus fumigatus GH7 endoglucanase over-expressed in Pichia pastoris stimulates lignocellulosic biomass hydrolysis. Int. J. Mol. Sci. 2019;20(9):2261. DOI 10.3390/ ijms20092261.

Wang K., Luo H., Shi P., Huang H., Bai Y., Yao B. A highly-active endo-1,31,4- $\beta$-glucanase from thermophilic Talaromyces emersonii CBS394. 64 with application potential in the brewing and feed industries. Process Biochem. 2014;49(9):1448-1456. DOI 10.1016/j.procbio.2014.06.003.

Wang S., Liu G., Wang J., Yu J., Huang B., Xing M. Enhancing cellulase production in Trichoderma reesei RUT C30 through combined manipulation of activating and repressing genes. J. Ind. Microbiol. Biotechnol. 2013;40(6):633-641. DOI 10.1007/s10295-013-1253-y.

Watanabe H., Tokuda G. Animal cellulases. Cell. Mol. Life Sci. 2001;58(9):1167-1178. DOI 10.1007/PL00000931.

Zhang P., Yuan X., Du Y., Li J.J. Heterologous expression and biochemical characterization of a GHF9 endoglucanase from the termite Reticulitermes speratus in Pichia pastoris. BMC Biotechnol. 2018;18:35. DOI 10.1186/s12896-018-0432-3. 